\title{
The Sanak-Kadang Jodhipati: A New Form of Virtual Radio Listeners Community
}

\section{Sanak Kadang Jodhipati: Sebuah Bentuk Baru Komunitas Virtual Pendengar Radio}

\author{
Zainal Abidin Achmad ${ }^{1}$, Heidy Arviani' ${ }^{2}$, Nobertus Ribut Santoso ${ }^{3}$ \\ ${ }^{1,2}$ Universitas Pembangunan Nasional Veteran Jawa Timur, Jl. Raya Rungkut Madya, \\ Surabaya \\ ${ }^{3}$ Universitas Atma Jaya Yogyakaarta, J1. Babarsari No. 44, Yogyakarta \\ *Corresponding author, e-mail: z.abidinachmad@upnjatim.ac.id
}

\begin{abstract}
The purpose of this study was to analyze the shifting form of a community of cultural radio listeners, Sanak Kadang Jodhipati, from an off-line to a virtual community. Since adopting Facebook, YouTube, and audio streaming, Radio Jodhipati FM's listeners have become part of a networked community. This study used a virtual ethnographic method, which allows researchers to conduct interviews and virtual searches from November 2019 to May 2020. The result shows that Sanak Kadang Jodhipati, as a social community, holds meetings in the Nganjuk Regency and other cities where Radio Jodhipati FM covers wayang kulit shows. As a virtual community, this community is more intensive in communicating through the WhatsApp group during the COVID-19 pandemic. The contents of the communication are not limited to discussing wayang kulit, gendhing, and other Javanese culture, it also addresses health, employment, legal, and political issues. Despite the diverse socioeconomic status, the members do not differentiate the form of communication, as fellow Javanese culture lovers.
\end{abstract}

Keywords: Cultural radio; COVID-19; Virtual community; Virtual ethnography

\begin{abstract}
Abstrak
Tujuan dari penelitian ini adalah untuk menganalisis pergeseran bentuk komunitas pendengar radio budaya, Sanak Kadang Jodhipati dari sebuah komunitas sosial off-line menjadi komunitas virtual. Sejak mengadopsi Facebook, YouTube, dan streaming audio, pendengar Radio Jodhipati FM telah menjadi bagian dari komunitas berjejaring. Penelitian ini menggunakan metode etnografi virtual yang memungkinkan peneliti melakukan wawancara dan pencarian virtual dari November 2019 hingga Mei 2020. Hasil penelitian menunjukkan bahwa Sanak Kadang Jodhipati sebagai komunitas sosial mengadakan pertemuan di Kabupaten Nganjuk dan kota-kota lain di mana Radio Jodhipati FM meliput pertunjukan wayang kulit. Sebagai komunitas virtual, komunitas ini lebih intensif berkomunikasi melalui grup WhatsApp, selama masa pandemi COVID-19. Isi komunikasinya tidak sebatas membahas wayang kulit, gendhing, dan budaya Jawa lainnya. Tetapi juga membahas masalah kesehatan, pekerjaan, hukum, dan politik. Meskipun berlatar belakang status sosial ekonomi beragam, tetapi mereka tidak membedakan bentuk komunikasinya sebagai sesama pecinta budaya Jawa.
\end{abstract}

Kata Kunci: COVID-19; Etnografi virtual; Komunitas virtual; Radio budaya 


\section{Introduction}

The competition of the private broadcast radio business is very competitive in line with technological developments (Achmad \& Alamiyah, 2015; Chang, 2013; Wilkinson, 2015). Competition demands creativity in creating program content based on the socio-cultural conditions of its audience (Achmad., 2019; Nurullah, 2019; Warren, 2005). Most private broadcast radio members of the Persatuan Radio Siaran Swasta Nasional Indonesia, PRSSNI Jawa Timur (Indonesian: Association of National Private Radio Broadcasting Indonesia of East Java), have adopted technology for broadcasting using several platforms, including Facebook, YouTube, Instagram, Twitter, and WhatsApp (Achmad \& Ida, 2019).

The adoption of platforms by private radios is in stages and selective. At first, Facebook seemed to be a standard technology because it can support the marketing field to obtain advertising. Nevertheless, on its way, each radio develops its broadcast technology. Some radios focus on developing audio streaming, adding Instagram, and moving forward with live streaming broadcasts via Youtube. Nearly all private radios in East Java have evolved towards convergence (Achmad \& Ida, 2019; PRSSNI Jawa Timur, 2018).

Progress towards convergence also occurs on cultural radios in East Java. One of which is Radio Jodhipati FM, located in Tanjunganom District, Nganjuk Regency. Cultural radio is a private broadcast radio with an identity (slogan) that represents Indonesian culture, has local cultural program content, and uses local language as an introduction to broadcasts. Its slogan is "Kumenyaring Budaya Nagari," which means the spread of Indonesian culture. The mention of this cultural radio arises from a limited discussion between researchers and two radio figures, Mr. Luthfi Abdullah and Mr. Djoko W. Tjahjo (Achmad \& Ida, 2019). The most relevant references to the definition of cultural radio come from some literature in Africa that calls it radio culture (Mudhai, 2011; Noone, 2013; Nuttall \& Michael, 2000; Odine, 2013).

Radio Jodhipati FM undertakes a gradual, cautious, and thoughtful shift to convergence. Starting from Facebook and audio streaming applications, the radio completes the convergence with Instagram. The adoption of the latest technology on Radio Jodhipati FM is YouTube and WhatsApp Group. The development of this technology adoption has an impact on the broader market to compete (A. Gazi et al., 2011; Schmidt, 2012).

The growth of cultural radios seems to be a catalyst for the improvement of the local content industries. The radio content industries not only disseminate information, entertainment, and education, but also disseminate values, lifestyles, norms, and culture to its audience (Chung, 2000; Grixti, 2006). Local content production expects to stem the flow of globalization because it provides the potential threat of the entry of foreign cultural content due to unlimited media access. The biggest target of cultural globalization is the younger generation. For this reason, Radio Jodhipati FM has the daunting task of creating and delivering content relevant to the younger generation's needs. A common difficulty faced is the reluctance of young people to accept cultural content that is traditional arts. One of the best ways to overcome this is the radio's willingness to support the commodification of traditional arts and culture, which is encouraged as local content that is worth selling to an audience of young people.

Since its inception, Radio Jodhipati FM has established positioning as a cultural radio, namely private broadcast radio, which has a dominant cultural program and broadcasts using local languages (Achmad., 2019). The main reason for choosing the 
positioning was the belief of its founder at that time, the late Mr. Joko Suprapto -that there was no private radio that specifically broadcasted Javanese culture. A thing that, according to him, is weird. How could Javanese, as the largest population on Java island, not have a radio representing Javanese ethnic identity? (interview with Director of radio Jodhipati FM, 28 November 2019).

The choice of positioning Radio Jodhipati FM as a cultural radio, at first, experienced various obstacles including rejection of licensing by the East Java Regional Commission-Indonesian Broadcasting Commission (KPID) for not using Bahasa Indonesia as the official language of broadcasting. Difficulties also persist in obtaining wayang kulit recordings and scarce recordings of Javanese songs (gendhing and langgam) and recruiting broadcasters who understand Javanese culture. However, all these difficulties can be overcome gradually (Achmad \& Ida, 2019). Since 2009, Radio Jodhipati FM has been developing other businesses that can support broadcasts, namely as an event organizer for wayang kulit shows.

Since proclaiming itself as Javanese culture radio, Radio Jodhipati FM has consistently never left Javanese cultural content. Even some radio program consultants in East Java consider that local cultural content will not produce much financial gain. Radio Jodhipati FM has convincingly overturned the estimation of radio business owners who underestimated local culture's selling ability. Positioning strategy to serve the community's needs towards Javanese culture makes Radio Jodhipati FM radio a very well-known radio to foreign countries. Some listeners claim to come from Philadelphia, Saudi Arabia, Kuwait, Hong Kong, Tokyo, London, and Suriname (Data from Facebook and Youtube accounts of Radio Jodhipati FM). Foreign audiences generally work as Indonesian Workers (TKI) and students. Although there is no valid data on local content needs in Indonesia, at least there are data from other countries used as a reference, that the current radio listeners need more local information (74.4\%), local music $(84.8 \%)$, information on religion $(65.5 \%)$. The data shows the high level of community support for local production (Suruhanjaya Komunikasi dan Multimedia Malaysia, 2017). In line with the research from The Office of Communications (Ofcom), as the UK's communications regulator, the vast majority of radio listeners in England valued and supported the role of local or cultural radios in providing local contents for local needs (Kantar Media, 2015), as well as community radios which have specific local content for specific local audiences (Atika et al., 2017). Furthermore, the local private radios are able to provide and to promote local content industry (Rahim \& Pawanteh, 2010). Providing local content industry is not merely to create and to publish local content in the forms of entertainment, information, and education programs, but is interpreted as an industry of culture. Radio Jodhipati FM can disseminate norms, lifestyles, and society values to its listeners.

This article is part of the research findings on the development of mediamorphosis of cultural radios located in East Java (Radio Jodhipati FM Nganjuk, Radio Sritanjung FM Banyuwangi, Radio Nada FM Sumenep, and Radio Media FM Surabaya). The research has been going on from 2017 to 2019 (Achmad, 2020a). The intensity of the ongoing communication between researchers and the listeners' community revealed new facts about the development of the Radio Jodhipati FM's listeners during the Pandemic COVID-19 period. This article aims to explain the change in the types and forms of interaction of Sanak Kadang Jodhipati community, which shifted from a real community to a virtual community through a WhatsApp group, as a virtual space that identifies Javanese culture. 


\section{Method}

This study uses a virtual ethnographic method, which is introduced by Christine Hine as a blend of traditional ethnography and internet ethnography (Achmad \& Ida, 2018). This method requires the willingness of researchers to explore the virtual and real life, and carry out various activities in it within a specified period (Hine, 2000). The study must consider the adequacy of interactions with the subject, the data requirements, and the analysis's design (Angelone, 2018; Hair \& Clark, 2003; Hine, 2017). As one of the principles of virtual ethnography with an intermittent process of involvement (Hine, 2004), the researchers collected data off-line from November to December 2019 and continued collecting data online from March to June 2020 (during pandemic COVID19).

As participants, researchers conducted a virtual search with personal accounts on Facebook and Youtube, also personal mobile numbers. The openness of researchers' identity is an essential requirement in virtual ethnography, as a way for researchers to enter the WhatsApp Group Sanak Kadang Jodhipati. The participatory involvement lead researchers to immerse into informants' activities related to making Javanese culture programs and shifting form of radio listeners' community from off-line social community to virtual community.

There were six informants in this study, two persons from the management of radio Jodhipati FM (Director and Program Director), one person as a Javanese Cultural Expert, one person as Dalang (from Solo), one person as the coordinator of Sanak Kadang Jodhipati listeners' community, and one person as a loyal listener as well as an information technology expert. Researchers collected information regarding 1) The history of Radio Jodhipati FM and the positioning as a Javanese culture radio, 2) The strategy of making Javanese cultural programs that suited to market need, 3) Strategies in involving loyal listeners to produce Javanese Cultural programs, 4) The mediamorphosis process in adopting Facebook, WhatsApp groups, and YouTube to support broadcast, 5) The shifting form of the Sanak Kadang Jodhipati as a radio listeners' community from social to virtual community, and 6) The communication content, theme, and intensity in Sanak Kadang Jodhipati WhatsApp group, during the COVID-19 pandemic.

This study collected data through direct and indirect ways. Directly, researchers interact with the subject (radio management, listeners community, and informants) through observation and interviews (online and off-line). This method helps researchers prove the validity of data sources, build trust levels, assess the honesty of informants, and overcome informants' anonymity (Schoneboom, 2007). Indirectly, researchers collect documents related to the research scope and related to the subject of study (Angelone, 2018; Hine, 2017). Some of these documents are Radio Jodhipati FM profiles and portfolios, photographs of off-air activities, broadcast recordings, broadcast schedules, articles on radio culture, informant profiles from various sources, articles, news related to the subject of study, and various relevant scientific literature.

Real field locations include offices and studios, production and song collection rooms, transmitter and broadcast equipment, socio-cultural surroundings, locations of off-air activities, the workplaces of informants, the daily and work activities of informants, the media habits of informants, as well as the gathering habits of informants. At the same time, the virtual locations that are the destination of the search include (1) https://jodhipatifm.co.id/ (2) https://www.Facebook.com/pages/1061-FmRadio-Jodhipati/493559194336063, (3) WhatsApp group "Sanak Kadang Jodhipati," 
and (4) https://www.Youtube.com/ channel/UCUuZjxuvC3XvPIrV9M30QLw. The use of those two fields was to obtain information about the informants' dynamics of behavior and social relations. This research considered the need for time to get adequate interactions with online and off-line social networks.

\section{Results and Discussion \\ The Influence of Socio-Cultural Context and Strategy of Making Cultural Programs}

The history of radio Jodhipati FM showed that socio-cultural context of the location influences the making of media content (Achmad, 2009; Achmad et al., 2018; Achmad \& Sawitri, 2012; Arviani, 2013; Shauma \& Achmad, 2015). The proposition found the truth on radio Jodhipati FM after moving offices from the Rejoso sub-district to the Tanjunganom sub-district. The move brought blessings to Radio Jodhipati FM's strengthened identity as a representation and cultural identity of Java, due to the strong influence of Tanjunganom as the center of Javanese culture in Nganjuk Regency. The Tanjunganom sub-district has several locations that are still thick with Javanese myths and traditions at certain times, such as ruwatan, nyadran, wayangan, and other sacred activities (Indrawati, 2019).

Several villages in the Tanjunganom sub-district have essential roles in the history of the Nganjuk Regency from the time of the collapse of the Mojopahit kingdom, Mataram's glorious era, to the Dutch occupation (Interviews with Mr. Sumadi and Mr. Purbowasesa, 9 December 2019). Stories about the Panji and the Mataraman preserved through the Timplong and Gedog puppet art can still be found in the Tanjunganom area. Even though Timplong puppet art originated from Jetis Village, Pace Sub-district was created by Mbah Bancol in 1910 (Wibowo \& Ardany, 2015). Traditional art performances such as classical Javanese dance, tayub, pogokan, and jaranan are also existed in Tanjunganom. Besides, Nganjuk Regency is known as waranggono's warehouse because 18 sub-districts have residents who work as waranggono (Pradhana, 2013). The word waranggono consists of two syllables wara and anggono, wara means female and anggono means singing art. Waranggono is a mention for female dancers who can dance and sing Javanese songs (gendhing).

The history of the Tanjunganom sub-district is always connected with the growth of tayub and waranggono. Located in Sambirejo village, there is a hereditary tradition called gembyangan waranggono (graduation of female Javanese dancers and singers' processors), the name of location is Punden Mbah Ageng. Candidates for waranggono deserve to be a waranggono if they have gone through a graduation procession by tayub dancing together. Tayub is an abbreviation of the words "ditata ben guyub" (arrangement to make a harmony), a type of dance arranged in a neat line with synchronous movements to create a harmonious atmosphere between dancers and audiences. Tayub is an entertainment art that provides a place for mutual interaction among people. Anyone who acts as a connoisseur of dance will not refuse to honor if they have received sampur (scarves)from waranggono. As the underlying philosophy of Tayub is the creation of harmony, anyone who appears does not represent a particular position in society but as a dancer. The harmony between citizens is a means of arousing solidarity among people to create unity and peace. Tayub art has a meaning loaded with moral values and valuable Javanese culture (interview with a Javanese culture expert, 9 December 2019). 
The socio-cultural context surrounding the location of Radio Jodhipati FM influenced programming policies and positioning strategy as a Javanese culture radio. Almost all traditional art developed in Nganjuk Regency became the content of cultural programs on Radio Jodhipati FM. At its inception, this radio was underestimated by other private radios located around Nganjuk, Kertosono, Kediri, Jombang, Tuban, and Bojonegoro. Radio Jodhipati FM indeed is a radio which has a different program and does not follow the trends of other private radios with an accessible broadcast format with dangdut songs or pop songs.

Data on the number of listeners from media research institutions is not a guaranteed accuracy of the actual number of listeners. Besides, the cost of buying the data is also expensive. Instead of using money to buy data, I better give it to the welfare of employees. Data from media research institutions is not essential. We measure the size of our listeners precisely from the beliefs of advertisers. Those advertisers tell us that our broadcasts have penetrated in remote areas such as Ngoro and Diwek (Jombang), Wates and Pare (Kediri), Lengkong (Kertosono), Saradan (Caruban), Tuban and Cepu. On every live broadcast of wayang kulit, advertisers come to us. Sponsors are also easier to obtain. So, the size of the listeners is the number of advertisements that buy our programs" (interview with Director of Radio Jodhipati FM, 12 December 2019).

Radio Jodhipati FM developed a strategy of making Javanese cultural programs suited to market needs and obtained financial benefits by involving cultural actors to design and manage broadcast programs. The cultural actors include dalang, waranggana, Javanese language teacher, Javanese traditional dance teacher, experienced niyaga (Javanese music instrument player), and Campursari song writers (Achmad et al., 2020). Often these artists and cultural actors act as guest announcers or co-hosts. They even gained the trust of management to design and nurture their cultural programs. One of the best strategies is having the commitment to introduce dalangs who are yet reputable from local areas, namely: Nganjuk, Jombang, Mojokerto, Lamongan, Kediri, Bojonegoro, Ngawi, Madiun, and Blitar. By performing in Radio Jodhipati FM, those dalangs become more widely known. Many local dalangs are less well-known because they rarely get tanggapan or orders to perform at various events such as ruwatan, marriage party, the rite of circumcision, and harvest celebration. Every time there is a wayang kulit performance by a local dalang, Radio Jodhipati FM has the initiative to offer to record it or broadcast it live. Through broadcasts, those dalangs succeeded in being able to exist and have a reputation. Usually, when those dalangs perform wayang kulit, they are entrusted with promoting Radio Jodhipati FM programs and activities.

\section{The Mediamorphosis Process and Shifting Form of Listeners Community}

The availability of convergence opportunities makes this radio adopted various combinations of forms of communication technology as a mediamorphosis process (Achmad, 2020b; Boer, 2000; Fidler, 1997). Radio Jodhipati FM developed a mediamorphosis process to communicate with its audience through a combination of personal communication devices with mass communication and the internet, which occurs in a single communication system. This system is called a form of convergence (Jenkins, 2006). The effort to realize the vision of "Kumenyaring Budaya Nagari" has become a spirit for Radio Jodhipati FM to digitize Javanese culture broadcasting, reducing the cost of internet data packages distribution, and facilitate listeners' access in 
foreign countries (Interview with Program Director, 12 December 2019).

Radio Jodhipati FM listeners are shifting into a new form. They are not just listeners; now they can see and read program contents presented on Facebook, YouTube, and WhatsApp group. They are referred to as networked audiences because they have lives and communicate through virtual spaces (Achmad \& Ida, 2019; Bonini et al., 2016; Bonini \& Monclús, 2015; Li \& Jung, 2018; Loviglio, 2005). Furthermore, the WhatsApp group becomes the most intensive media for communication between listeners and Radio Jodhipati FM's management. One of the latest ways for Radio Jodhipati FM to establish emotional closeness with its loyal listeners is to use the WhatsApp Group "Sanak Kadang Jodhipati." Members of this group have been the most loyal listeners since the founding of Radio Jodhipati FM. They were the ones who formed the listeners' community Sanak Kadang Jodhipati in 2007, at the first Radio Jodhipati FM office in Ngadiboyo Village, Rejoso District (Interview with the coordinator of Sanak Kadang Jodhipati listeners' community, 13 December 2019).
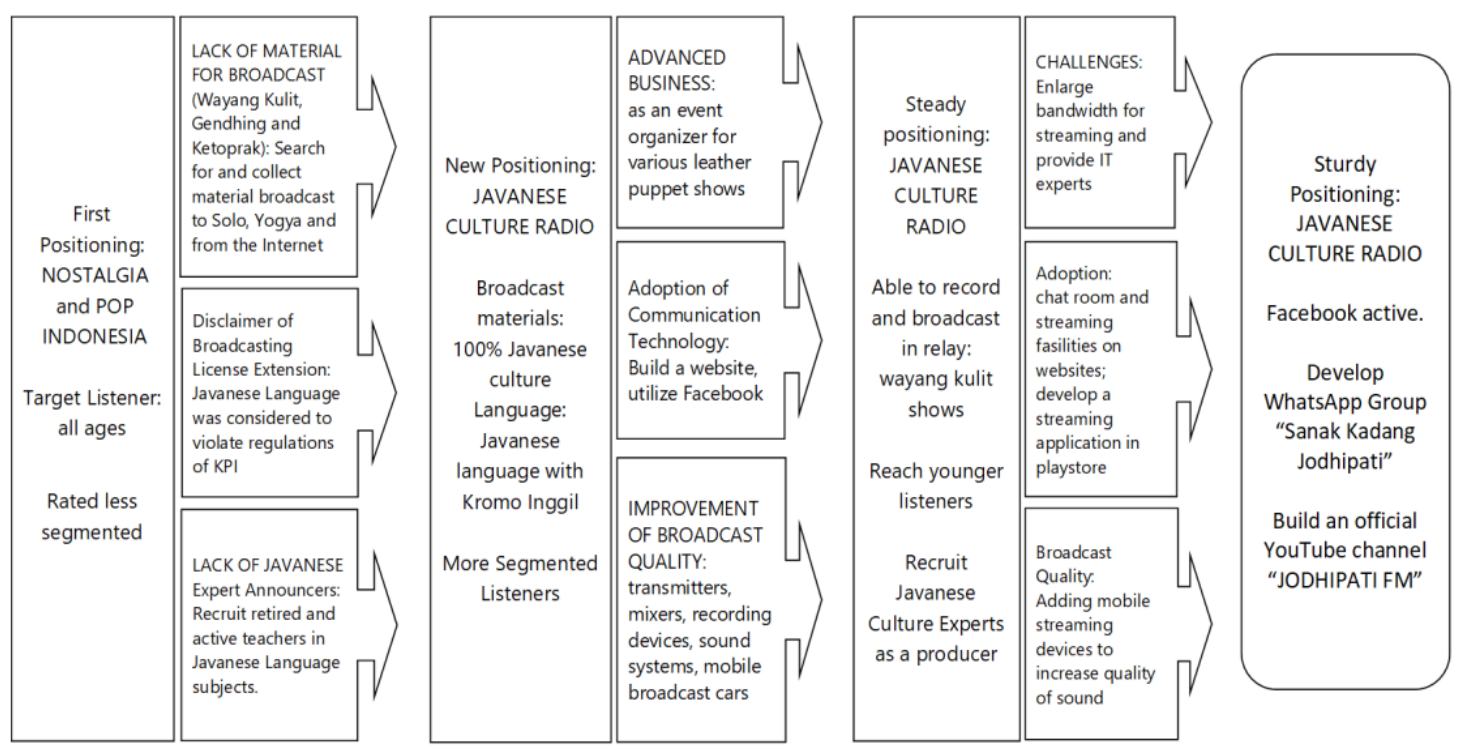

Figure 1. Mediamorphosis Process of Radio Jodhipati FM (source: Research findings)

Based on etymology, Sanak Kadang is the use of two words together, which have similar meanings. Sanak Kadang is a compound word from Javanese, a group of people bound by brotherhood or family (sanak) and direct blood ties (kadang). This conception of kinship within the Javanese family becomes the soul of relationships within the Sanak Kadang Jodhipati WhatsApp group. The concept of "Sanak Kadang" comes from Javanese language and has a meaning as a traditional kinship relationship. Yet, it has now shifted to a modern kinship relationship. Because of this, kinship currently has a new virtual form, the WhatsApp group. The radio listeners are members of the WhatsApp group and members of the virtual community who are part of a network society. 


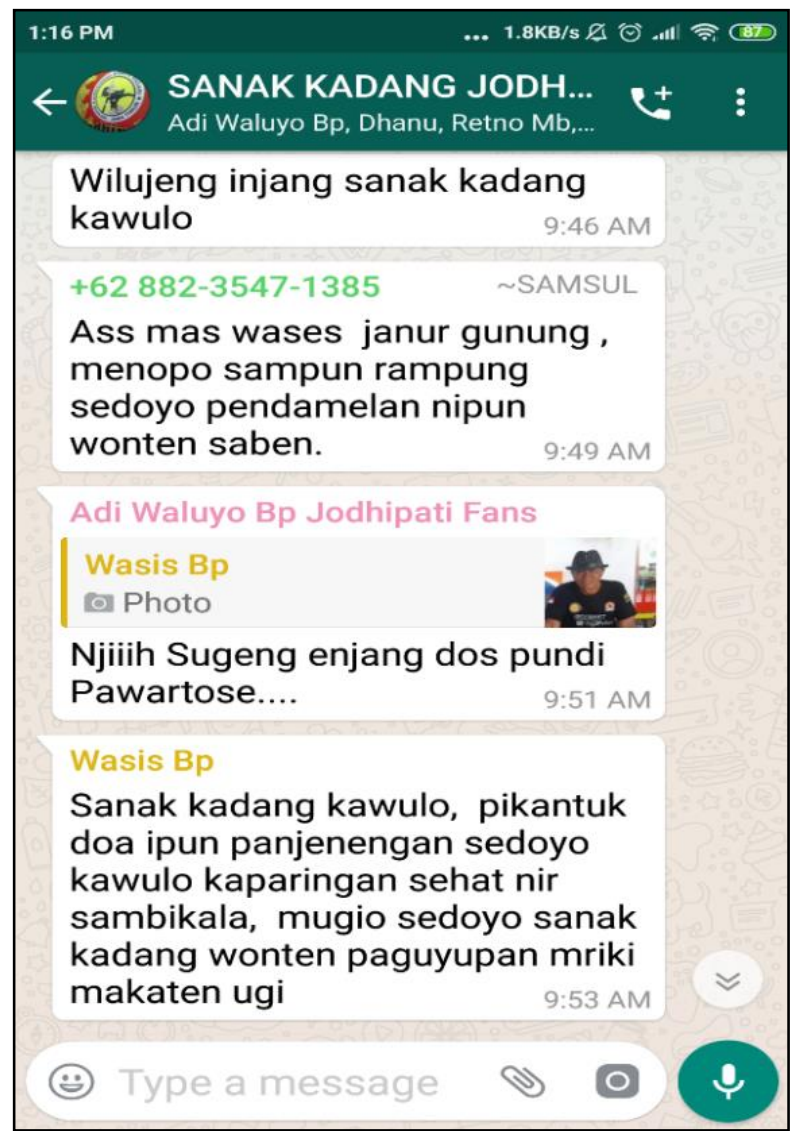

Figure 2. Communication activities using Kromo Inggil Javanese Language in WhatsApp Group (source: WhatsApp group Sanak Kadang Jodhipati)

WhatsApp is one of the fastest-growing interactive communication platforms for instant messaging. Its advantage is because it requires a small memory and can immediately install on a cell phone with any operating system. Specifically for Radio Jodhipati FM, this application is an additional channel for information distribution, as WhatsApp is recognized as the best radio partner to facilitate audience participation (Holton et al., 2016). WhatsApp provides the perfect solution because of its flexibility and cheapness, and it does not require additional technical tools to receive, store, and edit voice messages sent by listeners (interview via WhatsApp with Director of radio Jodhipati FM, 20 May 2020).

Radio Jodhipati FM relies on the WhatsApp group as the most active communication media that involves all elements in the radio station with loyal listeners. Uniquely, only loyal listeners or referred to as the best fans can become members of the group. The group admins select members through observations on Facebook and during interactive broadcasts. If they find a listener who has commitment and attention to the development of cultural broadcasts, they will offer to join the Sanak Kadang Jodhipati WhatsApp group 


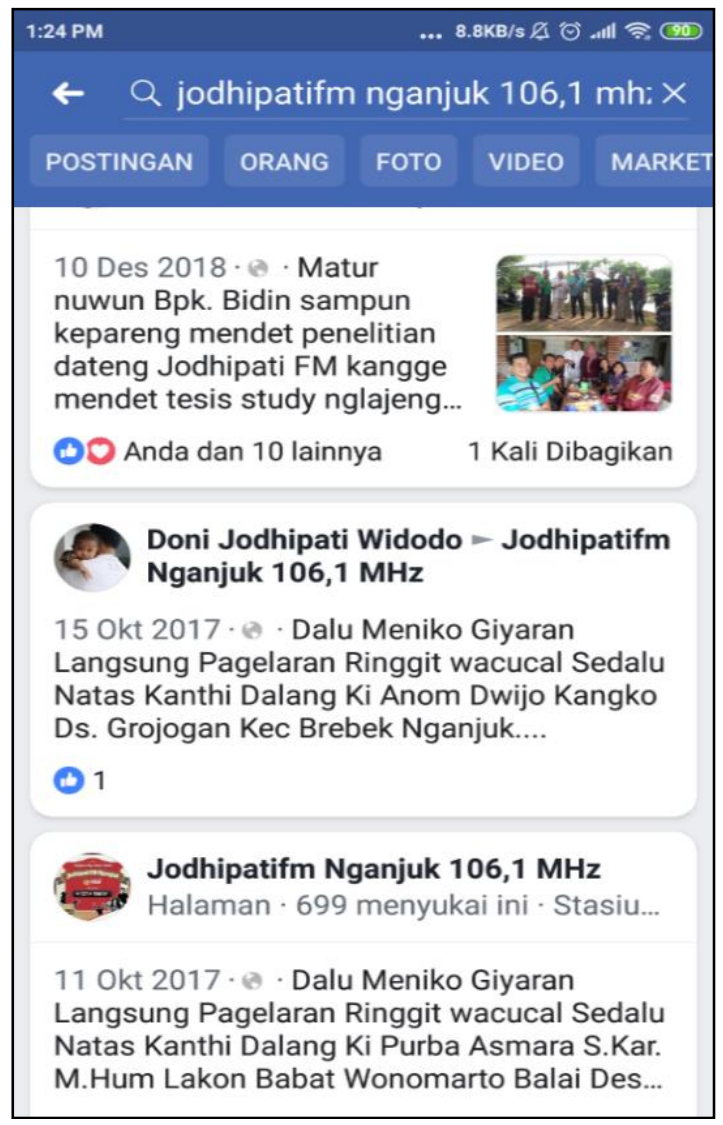

Figure 3. Interactive communication among the management, announcers, and loyal listeners in Facebook (source: Facebook Fanpage Jodhipatifm Nganjuk 106.1 MHz)

Since moving its office to Tanjung Anom Sub-district and adopting new technologies for broadcasting, Radio Jodhipati FM has a particular interest in the listeners' group of productive age of 25-40. Although this productive age group has lower loyalty than the 40-60-year age group, the age group has a very high social media activity and is very helpful for increasing the loyalty continuity of Radio Jodhipati FM listeners. There are two categories of listeners' age groups that have different characteristics of social media use. The age group of 25 to 40 years appeared more in conversations on the Facebook account of Radio Jodhipati FM, whereas the people from the age group of 40 to 60 years interact more through the Sanak Kadang Jodhipati WhatsApp group. This age group's professional background is diverse, including farmers, traders, retirees, teachers/lecturers, skipper rice fields, skipper livestock, shop owners, contractors, politicians, and bureaucrats. The similarity between these two age groups is always to use the Kromo Inggil Javanese language to communicate on all platforms.

Discussion in communication content in the Sanak Kadang Jodhipati WhatsApp group has free chat themes yet contains no racism, hate speech, pornography, nor political interests. The most frequent chats were discussing daily activities, work issues, traffic, weather information, wayang kulit performance agenda, and Javanese cultural events in East Java and Central Java. This group makes interaction and friendship more widespread among listeners by interacting with one another, sharing patience, and joking. Besides, the WhatsApp group Sanak Kadang Jodhipati provides several other benefits. For broadcasters, they get invitations as presenters at government agency 
activities, weddings, entertainment stages, product promotions, and religious activities. At the same time, management gets the addition of local advertisers. Furthermore, for listeners, they can develop business networks and even get a life partner. Some group members come from cities spread across the islands of Sumatra, Jawa, Kalimantan, Bali, Madura, Sulawesi, and Nusa Tenggara Barat (interview with a loyal listener, 13 December 2019).

The Sanak Kadang Jodhipati has been shifting from off-line social community form to virtual community through WhatsApp group. It has characteristics of a combination of interpersonal and mass communication. This new form is a new opportunity for better communication between the sender (private) and the recipient (public). In this virtual network, everyone has the same opportunity to talk, exchange text, audio, and video (Perdana \& Irwansyah, 2019). Simultaneously, everyone in the network has the same access to reading, watching, listening, and giving feedback. These communication activities can only happen in the WhatsApp group as a chat group and virtual instant messaging group (Herring, 2004).

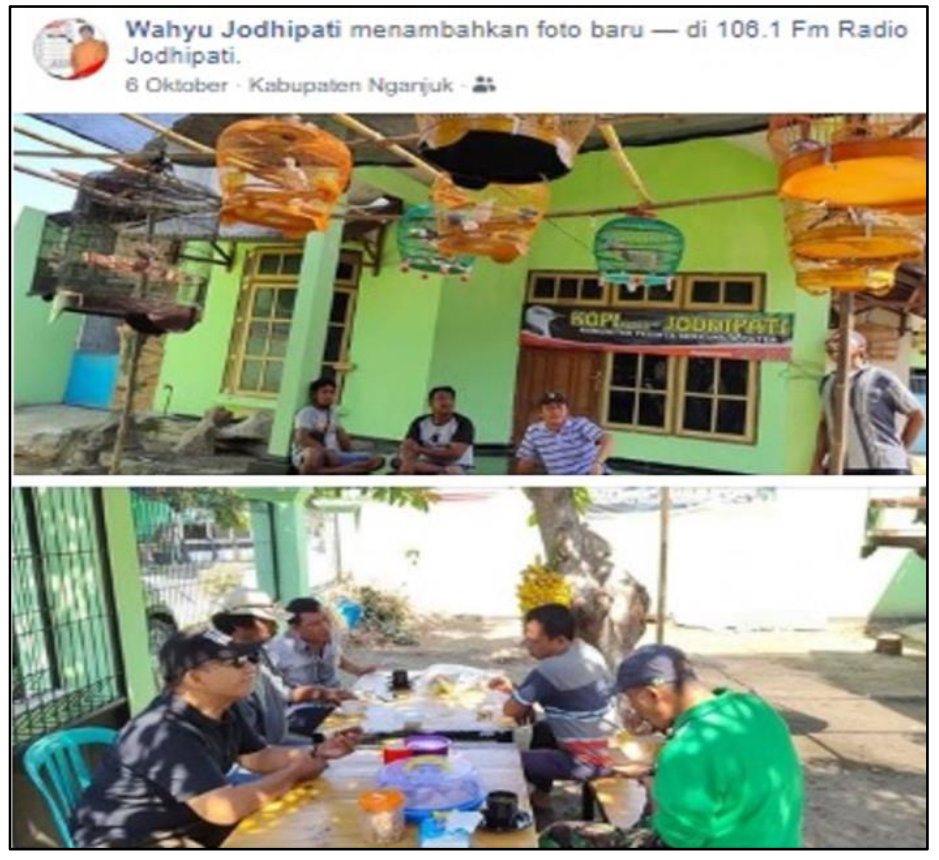

Figure 4. Discussion in "Ngopi Jodhipati" as an informal meeting room for the listeners' community (source: the Facebook account of Radio Jodhipati FM)

This community has a habit of gathering when watching a wayang kulit show or during Ngopi Jodhipati. Ngopi Jodhipati is a gathering activity for loyal listeners of Radio Jodhipati FM, discussing while drinking coffee, usually during work breaks (midday) or after work (late afternoon), located in a house next to the studio. This gathering activity can be attended among dalang, members of the WhatsApp group, managers, and broadcaster. Those who live in Nganjuk Regency can meet at the Sanak Kadang Jodhipati community headquarters located next to the Radio Jodhipati FM office on Jalan Gatot Subroto 19, Desa Dipan Barat, Tanjunganom Sub-district, Nganjuk Regency. Radio management always provides coffee and snacks for anyone who wants to stop by. They discussed many things, such as criticism of the announcer, criticism of advertising, local and national issues, the comparison of the dalang, plans for social activities, and plans to create program content. 
Increasing and expanding interaction between radio listeners and radio institutions is an effort to involve listeners in responding to and creating programming content (Sterling et al., 2009). Some results of these discussions produced the idea of a radio program as collaborative works among listeners, producers, and program directors. One of the radio programs produced by this joint work is Sruputan Jodhipati, which broadcasts every Wednesday night. The planning and execution of the Sruputan Jodhipati program result from the joint work show an indigenous participatory space.

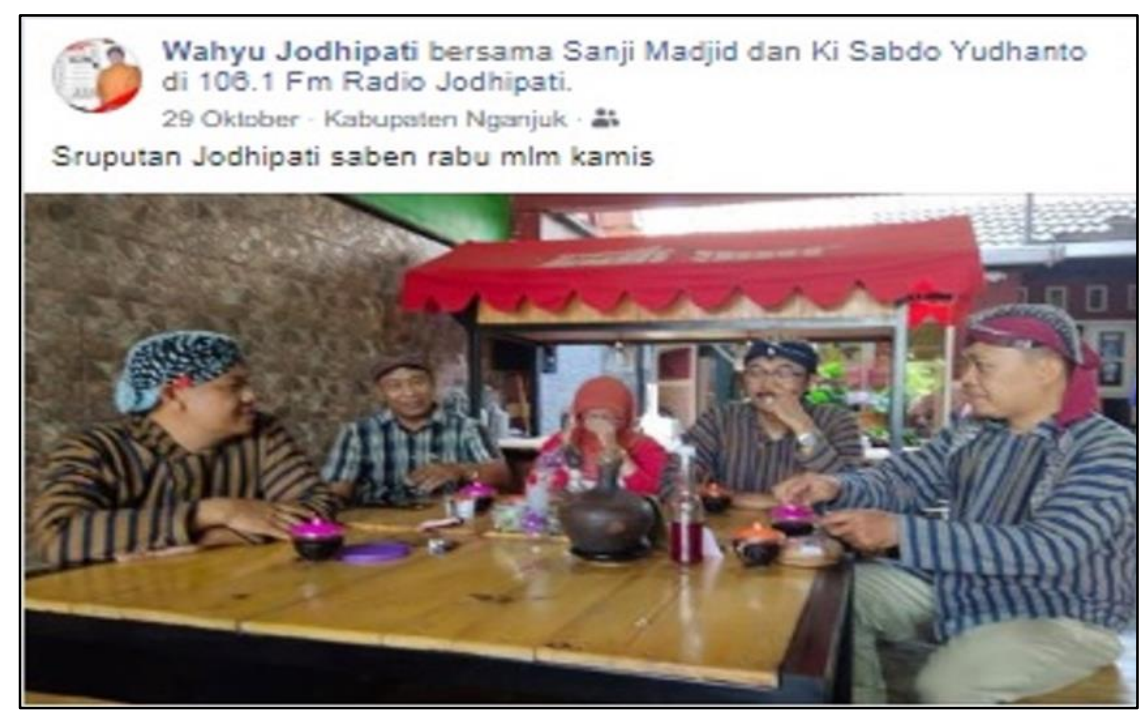

Figure 5. Sruputan Jodhipati is a commodification program began with a listeners' activity in the studio. This program is an embodiment of the public sphere because officials and the people can communicate egalitarian (source: Facebook fanpage of 106,1 FM radio Jodhipati).

WhatsApp group and "hang out together" (ngopi) become a production space, sales space, and consumption space. The more listeners listen, and the more discussion participants appear in the Sruputan Jodhipati program, the higher the capital potential gained. Radio Jodhipati FM has proven that Javanese cultural programs and the development of a public dialogue space through the Sruputan Jodhipati program have significantly brought in many advertisers and sponsors. During the program run, advertisers were able to manipulate the program's popularity for the benefit of advertisers, and some of the Sruputan Jodhipati program themes changed as a space for "sales." At the same time, management and listeners continued to make it a democratic space for participation.

A very fluid form of cooperation between the commissioners, directors, producers, program directors, and listeners of Radio Jodhipati FM shows the ongoing indication in the network society theory, namely the transformation of work and forms of work (Castells, 2010). The use of communication technology to support broadcasting has changed the form of private radio as a media company, shifting towards networked companies (Sugihartati, 2014). Radio Jodhipati FM's presence in the virtual world demands changes in managing work. The form of a company that initially had leadership and secondary structure became less strict and subtle and shifted to a structure that relied on the strength of informal cooperation.

The commissioner and director of the company Radio Jodhipati FM entrust workers with information management and production skills to create with the listening 
community to design Javanese cultural programs that provide profit opportunities. Discussions in the WhatsApp group as virtual space make it the space of flows as one of the indications in the network society theory (Castells, 2010), which identifies Javanese culture. The programming process at Radio Jodhipati FM is in line with the first indication in the logic of network society that organizations (cultural radio) that process their competitiveness by selling valuable content have understood the information economy (Castells, 2008). When the internet comes, Radio Jodhipati FM plunges into it and sees profit opportunities. This radio carried out the principles of capitalism and informationalism (Castells, 2004).

Virtual social communities such as the WhatsApp group can be reviewed based on the perspective of modern-mass society theory from Georg Simmel (1858-1918). One hundred years after Simmel, we are still relevant to renewing the understanding of the relationship between identity and city life in the information technology era (Chayko, 2015). The concept of 'the strangers' in the metropolis has found a new form of sociology. Metropolis used to be meaningful as a form of social structure where people gathered openly, but now the metropolis is virtual communities that live in networks or a network society (Castells, 2010; Fearon, 2004).

The virtual community has several key aspects, including (1) New ways of interaction among humans and new interactions in families, social groups, and work organizations. The interaction also has a new purpose: imaging, leisure motivation, seeking status, and maintaining social roles. (2) New ways for humans to interact with goods. Including the production, distribution, and consumption of goods and services. (3) New ways for humans to interact with time and space, namely the speed of travel and communication. (4) New ways humans interact with institutions, such as political organizations, schools, or public authorities (Bouchet, 1998).

\section{Conclusion}

As a virtual community, the Sanak Kadang Jodhipati WhatsApp group has created new conditions for relations between production and consumption. Networked virtual communities have formed new consumption patterns, one of which is that business relationships do not always aim for profit. In this position, Radio Jodhipati FM's management is the seller, while the listeners are the buyer. Technology and network society made Radio Jodhipati FM stay in the network.

The Sanak Kadang Jodhipati WhatsApp group is a fusion of the forms of social community, between before and when they are part of a networked community. Before the internet era, the Sanak Kadang Jodhipati community was only in contact with a small number of people, has concentric circle patterns, and consists of the same people. The community comes from neighboring environments and forms strong bonds as a family. Strong community ties limit individual desires and needs and absorb the individual fully and treat them as members of the group rather than as individuals.

When the internet era, the Sanak Kadang Jodhipati community, which has virtual space on WhatsApp group, changed into a big family and has many members from various cities in Indonesia and abroad. The socioeconomic status does not distinguish their forms and styles of communication as fellow enthusiasts and lovers of Javanese culture. The social circle in the Sanak Kadang Jodhipati WA group shows overlapping and a broad intricate pattern of information. That is, one can have membership in various WhatsApp groups. Someone will always adjust when joining and contacting the WhatsApp group. 


\section{Acknowledgements}

The authors would like thank: Head of Communication Science Department of Universitas Pembangunan Nasional Veteran Jawa Timur, Head of Communication Science Department of Universitas Atma Jaya Yogyakarta, Committee of The 6th International Conference on Social and Political Sciences (ICoSaPS) 2020 Universitas Sebelas Maret Indonesia, and reviewers of Jurnal ASPIKOM.

\section{References}

Achmad., Z. A. (2019). Integrasi Program Dakwah dan Budaya: Studi Etnografi Virtual Mediamorfosis Radio Nada FM Sumenep Madura. Jurnal Komunikasi Islam, 09(2), 238-263. https://doi.org/10.15642/jki.2019.9.2.239-263

Achmad, Z. A. (2009). Proses Produksi dan Vox-Pop Acara Freeday di Televisi Lokal SBO TV Surabaya. Jurnal Ilmu Komunikasi, 1(1), 29-36.

Achmad, Z. A. (2020a). Pergeseran Relasi Antara Pendengar Radio dengan Institusi Radio dalam Masyarakat Jaringan (Studi Etnografi Virtual pada Radio-radio Budaya di Jawa Timur yang Bermediamorfosis). Universitas Airlangga.

Achmad, Z. A. (2020b). REVIEW BUKU: Mediamorphosis: Understanding New Media by Roger Fidler, Thousand Oaks, California: Pine Forge Press (2003). In E. R. Nawangsari \& A. Kriswibowo (Eds.), Potret Masyarakat dan Kebijakan Pemerintah dalam Menghadapi Tantangan Pandemi COVID-19. Program Studi Ilmu Administrasi Negara, UPN "Veteran" Jawa Timur.

Achmad, Z. A., \& Alamiyah, S. S. (2015). Relation Between Political Economic of Media with the Strategies for Radio Positioning to Maintain the Existence of Commercial Radio (Case Study of JJFM Radio in Surabaya). International Conference on Democacy and Accountability (ICoDA), 1, 188-193.

Achmad, Z. A., \& Ida, R. (2018). Etnografi Virtual Sebagai Teknik Pengumpulan Data dan Metode Penelitian. The Journal of Society \& Media, 2(2), 130-145. https://doi.org/10.26740/jsm.v2n2.p130-145

Achmad, Z. A., \& Ida, R. (2019). The shifting role of the listeners in the mediamorphosis process of culture radio: A case study of Jodhipati 106.1 FM. Masyarakat, Kebudayaan Dan Politik, 32(3), 240. https://doi.org/10.20473/mkp.v32i32019.240-250

Achmad, Z. A., Ida, R., \& Mustain, M. (2020). A Virtual Ethnography Study: The Role of Cultural Radios in Campursari Music Proliferation in East Java. Etnosia: Jurnal Etnografi Indonesia, 5(2), 221-237.

Achmad, Z. A., Kinan, J. G., \& Artaria, M. D. (2018). Controversy on the Acceptance of Transgender Characterization in the Movie "Lovely Man." The International Post-Graduate Conference on Media and Communication (IPCOMC), 360-365.

Achmad, Z. A., \& Sawitri, D. K. (2012). Qualitative Study of the Ad Clear Destination London as an Effective Media of Promotion: A Study of a Football Player as a Celebrity Endorser ofthe Referent Power Emulation. In N. Wulan, A. Budiastuti, D. A. Kwary, R. Fanany, \& A. Baharuddin (Eds.), Urban Mobility: Textual and Spatial Urban Dynamics in Health, Culture, and Society (pp. 347-352). Faculty of Humanities and Faculty of Public Health, Universitas Airlangga.

Angelone, L. (2018). Virtual Ethnography: The Post Possibilities of Not Being There. Mid-Western Educational Researcher, 31(3), 275-295.

Arviani, H. (2013). Budaya Global dalam Industri Budaya: Tinjauan Madzhab Frankfurt Terhadap Iklan, Pop Culture, dan Industri Hiburan. Global \&Policy, 1(2), 130- 
141.

Atika, A., Lubis, D. P., \& Rangkuti, P. A. (2017). Tingkat Pemenuhan Informasi Petani Melalui Radio Komunitas. Jurnal ASPIKOM, 3(3), 435-446. https://doi.org/10.24329/aspikom.v3i3.169

Boer, M. de. (2000). Management of Mediamorphosis. Erasmus Universiteit.

Bonini, T., Caliandro, A., \& Massarelli, A. (2016). Understanding the value of networked publics in radio: employing digital methods and social network analysis to understand the Twitter publics of two Italian national radio stations. Information, Communication \& Society, 19(1), 40-58. https://doi.org/10.1080/1369118X.2015.1093532

Bonini, T., \& Monclús, B. (2015). Radio Audiences and Participation in the Age of Network Society (T. Bonini \& B. Monclús (eds.)). Routledge.

Bouchet, D. (1998). Information Technology, the Social Bond and the City: Georg Simmel Updated (About the Changing Relationship between Identity and the City). Built Environment (1978-), 24(2/3), 104-133.

Castells, M. (2004). Informationalism, Networks, and the Network Society: a Theoretical Blueprint. In M. Castells (Ed.), The network society: a cross-cultural perspective (p. 488). Elgar. https://doi.org/https://doi.org/10.4337/9781845421663

Castells, M. (2008). Materials for an exploratory theory of the network society. British Journal of Sociology, 51(1), 5-24. https://doi.org/10.1080/000713100358408

Castells, M. (2010). The Rise of the Network Society. Wiley-Blackwell.

Chang, Y. S. (2013). A study of the marketing position and strategy for serving the public interest and formulating programs for public radio stations. Problems and Perspectives in Management, 11(3), 47-55.

Chayko, M. (2015). The first web theorist? Georg Simmel and the legacy of 'The web of group-affiliations.' Information, Communication \& Society, 18(12), 14191422. https://doi.org/10.1080/1369118X.2015.1042394

Chung, P. (2000). The cultural others and national identity in the Taiwanese and South Korean media. GAZETTE, 62(1), 99-115.

Fearon, D. (2004). Georg Simmel: The Sociology of Space. Center for Spatially Integrated Social Science (CSISS Classics); eScholarship, University of California. https://escholarship.org/uc/item/7s73860q

Fidler, R. (1997). Mediamorphosis: Understanding New Media. Pine Forge Press.

Gazi, A., Starkey, G., \& Jedrzejewski, S. (2011). Radio Content in the Digital Age: The Evolution of a Sound Medium (A. Gazi, G. Starkey, \& S. Jedrejewski (eds.)). Intellect.

Grixti, J. (2006). Symbiotic transformation: youth, global media and indigenous culture in Malta. Media, Culture \& Society, 28(1), 105-122. https://doi.org/10.1177/0163443706059295

Hair, N., \& Clark, M. (2003). An Enhanced Virtual Ethnography: The Role Of Critical Theory. Exploring the Meaning of'critique'in ..., 44(0). http://merlin.mngt.waikato.ac.nz/ejrot/cmsconference/2003/proceedings/exploring themeaning/Hair.pdf

Herring, S. (2004). Slouching toward the ordinary: current trends in CMC. New Media \& Society, 6, 26-36.

Hine, C. (2000). Virtual Ethnography. Sage Publications Ltd.

Hine, C. (2004). Virtual Ethnography Revisited. In Online Reearch Methods, Research 
Methods Festival.

Hine, C. (2017). Virtual Ethnography: Modes, Varieties, Affordances. In N. Fielding, R. M. Lee, \& G. Blank (Eds.), The SAGE Handbook of Online Research Methods (pp. 401-415). SAGE. https://doi.org/10.4135/9780857020055.n14

Holton, A. E., Lewis, S. C., \& Coddington, M. (2016). Interacting with Audiences. Journalism Studies, 17(7), 849-859. https://doi.org/10.1080/1461670X.2016.1165139

Indrawati, C. (2019). Mitos-mitos di Kecamatan Tanjunganom Kabupaten Nganjuk: Analisis Struktur, Fungsi, Nilai Budaya, dan Pengaruh. Universitas Negeri Surabaya.

Jenkins, H. (2006). Convergence Culture: Where Old and New Media Collide. New York University Press.

Kantar Media. (2015). Local commercial radio content (pp. 1-101). The Office of Communications, UK.

Li, H., \& Jung, S. (2018). Networked audiences and cultural globalization. Sociology Compass, 12(January), 1-12. https://doi.org/10.1111/soc4.12570

Loviglio, J. (2005). Radio's Intimate Public: network broadcasting and mass mediated democracy. University of Minnesota Press.

Mudhai, O. F. (2011). Survival of 'radio culture' in a converged networked new media environment. In H. Wasserman (Ed.), Popular Media, Democracy and Development in Africa (pp. 253-286). Routledge.

Noone, L. (2013). Radio in the Digital Age: The Evolution of Radio Culture in A New Media Era. University of Dublin, Trinity College.

Nurullah, B. (2019). Konvergensi Media Radio Republik Indonesia (RRI) Bandung. Universitas Pasundan.

Nuttall, S., \& Michael, C.-A. (2000). Senses of Culture: South African Culture Studies (S. Nuttall \& C.-A. Michael (eds.)). Oxford University Press.

Odine, M. (2013). Use of Radio to Promote Culture in South Africa. Journal of Radio \& Audio Media, 20(1), 181-196. https://doi.org/10.1080/19376529.2013.777341

Perdana, A. A., \& Irwansyah. (2019). Model Interaksi Multi Kultur Dalam Ruang Virtual Whatsapp: Silaturahmi, Konflik, Leave Group. Jurnal ASPIKOM, 3(6), $1063-1075$.

Pradhana, E. K. A. (2013). Fungsi Seni Tayub Dalam Masyarakat Di Dusun Ngrajek Desa Sambirejo Kecamatan Tanjung Anom Kabupaten Nganjuk. AntroUnairdotNet, 2(1), 197-206.

PRSSNI Jawa Timur. (2018). Profil Anggota PRSSNI Jawa Timur. $\mathrm{http} / / / \mathrm{www} \cdot$.radiojatim.com/index.php?option=com_content $\& v i e w=\operatorname{article} \& \mathrm{id}=1 \&$ Itemid=154\#

Rahim, S. A., \& Pawanteh, L. (2010). The local content industry and cultural identity in Malaysia. Journal of Media and Communication Studies, 2(10), 215-220.

Schmidt, B. (2012). Interactivity on Radio in the Internet Age: A Case Study from France. In S. Gazi \& Jedrzejewski (Eds.), Radio Content in the Digital Age (pp. 28-34). Intellect.

Schoneboom, A. (2007). Diary of a working boy: Creative resistance among anonymous workbloggers. Ethnography, 8(4), 403-423. https://doi.org/10.1177/1466138107083559

Shauma, A., \& Achmad, Z. A. (2015). Efektivitas Iklan Politik di Televisi (Studi Deskriptif Kuantitatif Efektifitas Iklan Politik Aburizal Bakrie Versi Motivasi 
Anak Indonesia Pada Pemilih Pemula di Surabaya). Jurnal Imu Komunikasi, 7(2), $1-10$.

Sterling, S. R., O’Brien, J., \& Bennett, J. K. (2009). Advancement through Interactive Radio. Information Systems Frontiers, 11(2), 145-154. https://doi.org/DOI 10.1007/s10796-009-9170-3

Sugihartati, R. (2014). Perkembangan Masyarakat Informasi dan Teori Sosial Kontemporer. Kencana Prenada Media Group.

Suruhanjaya Komunikasi dan Multimedia Malaysia. (2017). Radio Users Survey 2017. Warren, S. (2005). Radio, The Book (4th ed.). Elsevier Focal Press.

Wibowo, A. M., \& Ardany, P. P. (2015). Sejarah Kesenian wayang Timplong Kabupaten Nganjuk. Jurnal Agastya, 5(2), 54-67.

Wilkinson, C. (2015). Young People, Community Radio and Urban Life. Geography Compass, 9(3), 127-139. https://doi.org/10.1111/gec3.12197 